\title{
Domesticating Social Justice Activism in the Global Era? Social Justice Movement in Times of Crisis
}

JIŘÍ NAVRÁTIL

Masaryk University, Czech Republic

ABSTRACT The contemporary economic crisis is sometimes labeled as the greatest crisis of capitalism since the Great Depression. Therefore one might expect it to become a perfect mobilizing grievance for the transnational social justice movement, which used to target the ideology of neoliberal governance and social consequences of unrestricted global financial markets. However, the current responses to the crisis and consequent austerity policies have remained mostly embedded at the national or even local level. The symbols of this struggle - Los Indignados and the Occupy movementhave focused on targeting national political issues rather than on organizing transnational coalitions and international protest events, while paying little attention to the role of global institutions and corporations. This article focuses on the case of Czech Republic and traces two broad processes-scale shift and identity shiftthat led to a broader change in the meta-logic of social justice mobilization. These processes and their constituent mechanisms have transformed the globally-focused and weakly-integrated movement into dense and nationally embedded coalitions that have started to target the national consequences of neoliberal governance instead of its global political foundations.

\section{Introduction}

This article aims to explore the evolution of the Czech social justice movement in the last decade. It traces the processes of its decline leading to the vanishing of its mobilizing capacity and transnational focus even in an era of global financial crisis. Generally, the outbreak of the global financial crisis in 2007 and the following austerity measures in many Western democracies 
might be expected to be a logical and convenient target and mobilizing issue for the Global Justice Movement (GJM) or for the global anti-capitalist Left in general. However, it seems that not only did the former transnational mobilizing structures remain largely quiescent, but most of the mobilizations related to the recent economic downturn and its social consequences have remained located mostly at the level of national polities, and have lost much of their transnational scope and political universalism. In other words, largescale supra-national mobilizations and the imagery of the anti-capitalist and reformist Left that flourished at the beginning of the new millennium across Europe or in America were not repeated. The article examines this "missed opportunity" of radical transnational politics. More specifically it asks what happened to the collective mobilization of the social justice movement after its heyday at the turn of millennium and during the recent economic crisis. What are the processes and factors that prevented another cycle of transnational social justice mobilization from taking place?

In my attempt to address these questions I focus on the evolution of the Czech social justice movement, which may illustrate some of the more general processes of transformation of the transnational social movements. As the Czech radical left became a firm part of the European branch of the global justice movement at the turn of the millennium-both in terms of framing, targets, and coordination of transnational protest events - its subsequent evolution also tells the much broader story of the transformation of global justice actors in liberal democratic settings. This article builds upon the theoretical framework of Dynamics of Contention as formulated by the McAdam, Tarrow and Tilly (McAdam, Tarrow, \& Tilly, 2001; McAdam, Tarrow, \& Tilly, 2008; Tilly \& Tarrow, 2007). Following the theoretical assumptions of this perspective, and drawing on previous research, the article also outlines a more general scheme of the possible path of a detransnationalization of political contention. The article suggests that the transformation of the Czech social justice movement - or its decline-was the outcome of two intertwining social processes: a scale shift, and an identity shift. These consisted of a series of environmental, relational and cognitive mechanisms, which generally turned a trans-nationally oriented and nationally rather isolated actor back into a nationally-focused and nationallyembedded one.

While it is often agreed that it is the supra-national organizational structure that qualifies a social movement as a genuine transnational subject, also there may be other aspects of collective mobilizations that make it transnational in a broader sense - such as protest issues, targets or mobilizations - while the rest of them may remain embedded in national or local context (cf. Rucht, 2009, p. 207). In this article I rely on the latter understanding of a transnational collective action for two reasons. First, it brings in a more dynamic perspective on the shifts between various aspects and levels of contemporary collective action, and second, it befits better to the Czech social justice actors and protests that only transiently qualified as "fully transnational" subjects in a strict sense of the term. This implies that the transnational dimension of 
collective action is perceived here as more flexible, less enduring and always partial (most notably in the case of collective identity), and firmly rooted in the local or national sphere. Therefore, the article considers different scales of contention within a particular cycle of protest or field of activism not as mutually conflicting but rather as complementary ones.

The structure of the article is as follows: the Czech social justice movement and its rise as a transnationally-oriented actor in 2000 is introduced. Next, the theoretical outline of the article is laid out, focusing on the Dynamics of Contention (DOC) perspective, and types of mechanisms that transform political contention - environmental, cognitive and relational — are described. The article continues with a description of the data and methods used. Fourth, the evolution of the Czech social justice movement between 2001 and 2011 is described in terms of environmental, relational and cognitive mechanisms. Finally, the whole process of transformation of the movement is outlined and evaluated, and general conclusions are drawn from the analysis.

\section{The Rise of the Czech Global Justice Movement (1990-2000)}

The regime change in 1989 set up special conditions for the evolution of the Czech social justice movement consisting of the radical Left social movement organizations (SMOs) that constituted its ideological and organizational backbone. The split between the communist Left and the other streams of the radical Left soon became embodied in the persistent cleavage between the collectivist (sometimes labeled as "authoritarian") Left and the libertarian one, even if the former had also consisted of newly-founded Trotskyite or Marxist SMOs with strongly negative attitudes towards the ancien régime (Bastl, 1999). The initial ideological fragmentation on the radical Left slowly gave way to more coordinated efforts among the libertarian (anarchist, autonomist, squatting) and radical environmental groups, which became more integrated in a rather indirect fashion via the internalization of the existing symbolic frameworks and identities of Western GJM, and via their affiliations with other transnational organizations (Císař \& Koubek, 2012).

From the very beginning, however, the Czech political environment was largely unreceptive to radical Left ideologies and frames of reference, which led to both the public marginalization of the movement, and to changes in its focus. In other words, most of the public events organized by the movement in the mid- and late 90's were focused on the negative impacts of globalization, but in more particular and indirect ways. Generally, the political economy of global capitalism (neoliberalism, economic injustice) remained strategically neglected, and globalization was targeted mostly as an issue of "corporatism." Typically, the impacts of globalization on culture ("coca-colonization" or "McDonaldization"), environment (gentrification, automobilism) and communities (commercialization of life) were examined and criticized (Kolářová, 2008, p. 4; Růžička, 2007, p. 37). The main type of protest event in this period, symbolizing the rising integration of Czech 
social justice SMOs into transnational structures, were the street parties that were explicitly inspired by the repertoire of People's Global action, Reclaim the Streets, and other Western networks (cf. Císař \& Slačálek, 2007, p. 2). The street parties started in 1997, and the largest took place in 1998 and 1999 with two thousand and five thousand participants, respectively, which was interpreted as a clear success for the movement.

However, in terms of building a transnational actor out of the existing social justice one, the International Monetary Fund/World Bank (IMF/WB) summit in September 2000 was a clear milestone - not just in terms of the number of participants, but also in terms of inter-organizational integration, and because of its supra-national character and importance for global justice activism in general. At the same time, because of these and other circumstances, the impact of this event on the Czech social justice movement is hardly comparable to other domestic processes and events (Císař, 2008, p. 148; Kolářová, 2009, pp. 50-55). The preparatory activities that were so important for the integration of the Czech social justice movement began in mid-1999, and led to the creation of an unprecedentedly wide coalition of domestic and foreign SMOs (Iniciativa proti ekonomické globalizaci [Initiative against economic globalization], INPEG) in close coordination with transnational GJM actors like Peoples' Global Action (PGA), Indymedia and others (Welsh 2004). Despite the fact that the majority of radical Left actors involved themselves in the process of organization through a single platform (INPEG), there were still some networks that participated in the event but were involved in the preparatory process through the alternative platform "Stop IMF!" (Trotskyites, communists). At the end of the day, there were several series of separately-organized protest events during the summit, but both streams of the movement eventually participated in some major marches and demonstrations. Therefore, the event was a success not only in terms of the number of participants (estimated between ten and twelve thousand, many of them coming from abroad) but also because of the unprecedented (albeit temporary) integration of various streams of the Czech social justice movement jointly participating against the same enemy. Also, because the symbolic integration of the movement was complete. During the preparation for the event and the event itself, the former local environmental, cultural and political claims were shifted both upwards and outwards towards a more explicit political economy framing. Due to the extremely strong presence of foreign networks and groups, the event aimed at an open critique of the international economic system and its ideological roots.

The event represented a completion of the process of integration of the Czech social justice movement by way of confirming its transnationallyembedded collective identity. The "global justice" identity and framing that was inspired by Western activism and contention was internalized by particular streams of the Czech social justice movement, isolated from one another and working instead through their connections with foreign counterparts and media. While the event led to the strengthening of the transnational dimension of the movement in terms of its symbolic aspects, it also exposed its very 
low level of practical inter-organizational integration. This feature emerged in the preparatory strategies and cooperation during the protests. Even if all these activities were fostered by the extraordinarily strong presence of the movement's foreign counterparts, participation by activists from abroad, and the presence of the international media, the practical fragmentation of the movement along the lines of its primary ideological identities still remained. In other words, after the event the Czech social justice movement became better integrated symbolically, but its social and inter-organizational embeddedness remained on almost the same level as before.

However, the arrival of the global financial crisis to the Czech Republic after 2008 found a social justice activism of a very different type (Navrátil \& Císař, 2014). Public protests were mostly organized by recently-founded, well-integrated and broad Czech social justice networks (e.g. ProAlt, or Stop vládě [Stop the government]) that were formed by the former Czech global justice actors and joined by other domestic SMOs. However, these framed the protests almost exclusively on the national or even local level, while targeting the government and its economic and social policies, and justifying their activities as democratic resistance by the citizens against the arrogance and corruption of national political elites. Despite the participation of most of the radical Left SMOs, there were almost no signs of anti-capitalism or diagnostic framing that would rely on broader ideological schemes and identify the roots of the financial crisis or logic of austerity measures in the neoliberal political order and its doctrine. So, what has happened to Czech social justice activism? How has the movement evolved? And what were the key factors and mechanisms in the process of its transformation?

\section{Changing Context, Networks, and Perceptions}

Theoretically, this article builds upon the dynamics of contention framework as formulated by McAdam, Tarrow and Tilly (McAdam, Tilly, \& Tarrow, 2001; Tilly \&Tarrow, 2007; McAdam, Tilly, \& Tarrow, 2008). More particularly, it assumes that process-based rather than a variable-based perspective could help us identify causal relations within the interactive multi-actor dynamics in the field of political contention. Furthermore, it assumes that these relations consist of a series of mechanisms and processes that recur across a variety of episodes in contentious politics. The mechanisms are defined here as "delimited changes that alter relations among specified sets of elements in identical or closely similar ways over a variety of situations" (McAdam, Tilly, \& Tarrow, 2008, p. 308). In this view, social processes are concatenations of such "building units"-mechanisms. Therefore, social processes may be defined as a more complex set of interactions than mechanisms, because they are treated here as a composite of several mechanisms (McAdam, Tilly, \& Tarrow, 2001, p. 27). In this sense, mechanisms are best differentiated because of their recurrent character, while processes may combine these mechanisms in different ways and with various outcomes (2001, p. 28). 
In order to understand more fully the dynamics of the different factors determining the evolution of the Czech social justice movement, this article opts for this mechanistic perspective in the study of contentious action.

At least two key broad and closely-intertwined processes consisting of several mechanisms worked to transform the Czech social justice movement after it reached its "transnational" peak in 2000. The first is the process of downward scale shift that demotes the coordination of collective action to a more local level than at its initiation (Tilly \& Tarrow, 2007, p. 94). In other words, while the claim-making of the Czech social justice movement during its "global justice" period largely targeted transnational institutions and symbols, at the end of the process the national and local consequences of economic hardship became the dominant issue of the movement, which also framed issues in a way that was resonant in Czech society. The other process is an identity shift, which is broadly defined as the emergence of new perceptions of the actors themselves and of the essences that constitute the movement. More particularly, the Czech social justice movement in its "global justice period" defined itself primarily as a member of a transnational movement fighting globalized capitalism and its consequences all over the world, often despite the attitudes and opinions of other Czech SMOs and citizens (Navrátil, 2010). However, this changed after the arrival of the global financial crisis, when the movement instead began to define itself more as an advocate for Czech citizens, targeting national and local institutions and political elites and becane embedded in a national coalition of SMOs and networks. In other words, the emphasis on symbolic transactions and active alliances with ideologically-aligned and often foreign counterparts gave way to intensive cooperation within broad coalitions of domestic SMOs, while suppressing the ideological aspects and supra-national framing of protest issues.

The process of an upward scale shift has been described in many analyses typically focusing on the rise and mobilization of the Global Justice Movement (cf. Ayres 2004; della Porta \& Tarrow, Juris, 2008; Munck, 2007; Smith, 2008; 2005; Tarrow, 2005). On the other hand, while the processes of localization of protest in the global era have also been described and analyzed (Hamel, Lustiger-Thaler, Pieterse, \& Roseneil, 2001; Navrátil \& Císař, 2014; Starr \& Adams, 2003), there is still a lack of procedural analyses of the decline of the scale of contention in contemporary societies.

In analyzing the composition of both processes and tracing their constituent mechanisms, this article differentiates among their environmental, cognitive and relational types (cf. Heaney \& Rojas, 2011; McAdam, Tilly, \& Tarrow, 2001), and makes use of a catalogue of existing concepts of processes and mechanisms that have been analyzed so far (Tilly \& Tarrow, 2007, pp. 214-217). The environmental mechanisms stand for "externally generated influences on conditions affecting social life" (McAdam, Tilly, \& Tarrow, 2001, p. 25). Namely, these are shifts in the societal and political environment where actors operate and mobilize that affect the strategies and outcomes of political protest. In this article I conceive of environmental mechanisms as 
the shifts in threats or opportunities that might have (if thus interpreted) largescale consequences for a particular field of activism (cf. Almeida, 2003; Alimi, 2007; Goldstone \& Tilly, 2001). Among the many environmental changes in the field of the Czech social justice movement, two were of extraordinary importance for the transformation of key aspects of its collective identity and focus during the time of recent crisis. First was the public announcement of an inter-governmental agreement between the U.S. administration and the Czech government to install a U.S. military base in the Czech Republic. This led to a decisive transformation in the logic of collective action in the field of anti-war activism in which the social justice actors had been largely involved since 2003. Second was the transformation of the political context in the field of socio-economic contention in 2008 and 2009, when extensive domestic economic reforms were effectively launched by the government, and the first impacts of the economic crisis appeared in the Czech Republic.

Relational mechanisms refer to the transformation of "the connections among people, groups and interpersonal networks" (McAdam, Tilly, \& Tarrow, 2001, p. 26). There were two key relational mechanisms in the Czech case: the brokerage mechanism producing new connections between nonconnected actors and fields of activism, and defection, or the discontinuation of existing relation between actors or networks. In addition, the mechanism of renewal of previously existing alliances - emulation (Tilly \& Tarrow, 2007, p. 215) - also appeared. Basically, while the Czech social justice movement has taken off as a set of weakly connected and highly profiled collective actors with clearly defined ideological boundaries, this slowly began to change at the peak of the global justice protests, and coalitions became more frequent during the era of the anti-war campaign.

The term "cognitive mechanism" denotes the transformation of a perception on the individual and collective level (McAdam, Tilly, \& Tarrow, 2001, p. 26). Most importantly, it links the structural changes in a movement's environment with its perception and interpretation on the part of its activists or its constituency. In this article, the single most important cognitive mechanisms were the attribution of a threat or opportunity to a particular shift in political environment, and changes in the collective identity of the movement through the mechanisms of boundary deactivation and formation.

\section{Data and Methods}

This article builds on both quantitative and qualitative data. The former consists of two protest event datasets, with protest event being the unit of analysis. While the first was generated via official media sources ${ }^{1}$ and is used to map long-term and broader shifts in the trajectory of the Czech social justice movement, the second focuses on the field of anti-war activism and is used to illustrate the relational and cognitive mechanisms that were part of the movement's transformation in this field of contention. The protest event is defined here as an actual gathering of at least three people convened in a 
public space in order to make claims that bear on the interests of an institution/ collective actor. Only real episodes of collective action are included; threats of resorting to collective action, such as strike alerts, were excluded. Petitions were excluded from the analysis.

The first dataset (PEA Left, $\mathrm{N}=471$ ) is based on the electronic archive of the Czech News Agency (CAN) which was searched for news between January 1989 and December 2011 using selected keywords. The following variables were coded for each event: date, place, duration, collective participants and organizers, number of individual participants, main issues and framing and their scale, target of the claim, repertoire, reaction of elites, and police activity. All news covering any protest event was selected and coded. The whole dataset consisting of 6524 protest events was used to sample events that have taken place since 1990 and in which one of the organizers was a social justice actor, defined as an actor raising explicit social justice claims (typically radical left-wing SMOs-anarchist, communist, Trotskyite, Marxist or other left SMOs). Generally, I consider the year 2009 to be the start of the contention related to the global financial/economic crisis, as the first claims explicitly related to the crisis appeared in January 2009.

Four key variables were used in the present analysis. First, the target scale was coded as national/sub-national or supra-national according to the nature of the main target of the event. Nine types of targets for each event were re-coded as national/local (nationwide political institutions, courts, local political authorities, regional political authorities, welfare state) or supranational (EU, international institutions and other states), or others (non-profit organizations, private companies). The ratio of national and supra-national targets was analyzed. Second, two main protest issues were coded for each event (performance of state institutions and the quality of democracy; historical justice/recognition; the EU; economic issues; industry; urban planning; social policies; cultural and sport policies; agriculture; consumer issues, domestic security, foreign policies and war; environment; women rights; GLBT rights; minority rights, other human rights; and religion), and the five most frequent ones were selected for analysis. Third, event attendance was recorded. In cases when the exact number was not available (several dozen, several hundred etc.), its lower boundary was coded (20, 200, etc.). Fourth, the number of actors coordinating the protest events was recorded, and the average number of SMOs co-organizing the event was counted.

The second dataset (PEAAnti-war, $\mathrm{N}=287$ ) was generated by triangulating several key resources, and covers Czech anti-war activism between September 2002 and April 2009. The whole period under study (2002-2009) is divided into three successive phases (September 2002 - December 2002; January 2003 - July 2006; August 2006 - April 2009) according to the evolution of the political environment, and two ruptures between these periods are conceptualized as environmental mechanisms launching further chains of events. First, the press monitoring database Anopress, which covers news articles from all key nationwide and local (both printed and electronic) newspapers and journals, was used to generate a list of protest events within 
the period under study (from the start of the protest cycle against NATO in September 2002 to Obama's visit to Prague in April 2009 to announce his willingness to start the process of nuclear disarmament, settle US-Iran relations, and re-evaluate the deployment of a US anti-missile radar base in the Czech Republic). The web pages of relevant SMOs that engaged in antiwar activism were another regular source of information (e.g. Haddenn \& Tarrow, 2007). The other sources of information were the alternative and activist media, personal e-mail communications, and interviews with the representatives of the most important groups and networks. The following types of events or activities were not included in the dataset: running an information stand, events that were announced as anti-war but contained only other-than-anti-war claims (typical for the extreme Right), counterevents to anti-war events, referendums, and events where anti-war claims were absolutely minor ones (typically for political parties during election campaigns). The following variables were coded for each event: location, time, organizing and participating groups and organizations, number of participants, repertoire, number of individual participants (computed as an average of all values that were available), and main claim of the event. Also, any overall claim that was raised during the event was recorded and coded (either the direct open claim was recorded from speeches and interviews for the media, or it was reconstructed from banners and pickets). Because of the character of some events (e.g. local events that were not covered by the media in much detail), only $69 \%$ of claims raised at the events were recorded (100\% from the first period, 38\% from the second, and 30\% from the third). Recorded claims were coded along two dimensions: first, the basic scale of the claim was coded (international/global or national/local); and second, the key content component of the claim was distinguished (economic, democratic or environmental). The categories for coding were created inductively from the data.

Identification of the cognitive mechanisms related to the opening of political opportunities relied mainly on the analysis of the public discourse within the different periods of anti-war campaigns (opinion polls, newspaper articles, press releases of the government), and on interviews with activists. Identification of the cognitive mechanisms related to the intensification of the threat was based on an analysis of the framing of protest events, where the scale of framing represents the extent to which the issue (threat) was perceived as imminent and close to the domestic environment, and on the interviews with activists.

Identification of the relational mechanisms and emulation is based both on the activist interviews and on the social network analysis (SNA) that was applied to protest event data. The protest coalition, that is, ties between two or more SMOs, exists when these SMOs cooperate on the same protest event (i.e. sharing time, place, and attendance). The platforms or coalitions that arose within the different periods of anti-war campaigns were broken down into particular groups and organizations in order to make the single SMO the unit of analysis. The tie between SMOs is treated as undirected; in 
other words, when two groups took part at the same event, the tie is always considered symmetric. The reason is that anti-war actors do not take part at the event without the consent of the other organizing or participating actors; the co-occurrence of actors is thus conditioned upon the mutual agreement of all participating actors. The tie here represents the acted-upon willingness and capacity of the group to cooperate with other group(s) within the protest event, and to contribute to the success of the event either by mobilizing their own members and supporters or by assisting with logistics and know-how. The original 2-mode (affiliation) network that was created from the protest event data for each of the three periods under study was transformed into one-mode valued directed network. The value of the arc in the weighted cooperation networks equals the number of joint co-occurrences of two groups at some anti-war protest event. Self-loops within all networks were deleted. Events that were not organized by SMOs were not included in the SNA. Visual analyses were conducted in UCINet (Borgatti, Everett, \& Freeman, 2011).

The third main source of data are articles in the activist journal Solidarita (Trotskyite) and qualitative semi-structured interviews with three key representatives of Czech social justice SMOs, conducted in order to clarify the role of key factors, and to identify the mechanisms that were in play in the process of the movement's transformation. The respondents were active in different anti-war campaigns, and together they represent three different key ideological platforms that took part in the campaigns: anarchist, Trotskyite, and religious.

\section{Evolution of the Czech Social Justice Movement}

The early formation of the Czech global justice movement clearly relied on transnational backing, and the movement went through the process of transformation soon after the Prague event of 2000 was over. The Czech social justice movement then entered into the next phase of its evolution.

\section{Evolution of the Czech social justice movement: Three periods}

In quantitative terms, the evolution of the Czech social justice movement (SJM) might be described as consisting of three major phases that broadly correspond to major shifts in the political context relevant to the movement: the first phase of renewal (1990-1992), the second phase of expansion (1993-2000), and the third phase of decline (2001-2011).

The first phase (1990-1992) might be described as post-1989 euphoria, when the radical Left was trying to seize the attention of the public and bring in the left political agenda. Both freshly formed anarchist and autonomist groups and networks, and communist organizations soon became very active in organizing public protests (see Figure 1). The second period in the evolution of the movement started with the sharp fall in protest activities in 1993, and was characterized by slow but persistent re-activation and intensification of the movement's protest activities, which peaked in 2000, 
"the year of miracles." Since then, the movement has experienced a clear decline that persisted even through the arrival of financial crisis to the Czech Republic in 2009.

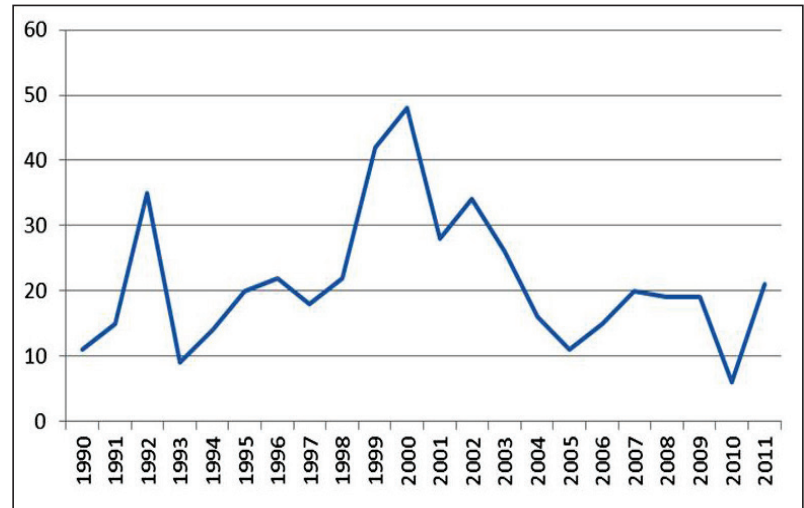

Figure 1: Number of protest events (1990-2011)

Source: PEA Left

Not only were the social justice SMOs very active in the early 1990s, but their reception by the citizens was relatively positive, as illustrated by the high level of participation at the events, especially in 1991 (see Figure 2). However, the dynamics of event participation in the next phase contrasted with the protest activity of the SMOs: despite higher activity by the SMOs in the second phase, the annual attendance at events was lower, if more stable, than in the previous period. On the other hand, in the last phase the general decline in participation at protest events organized by social justice SMOs paralleled the lower activity of social justice SMOs.

Finally, the third period (2001-2011) was evidently an era of decline for the movement. The indicators of activity for the movement-both the number of events and attendance by members and sympathizers - steadily declined after 2000, with few exceptions (2006-2009 and 2011).

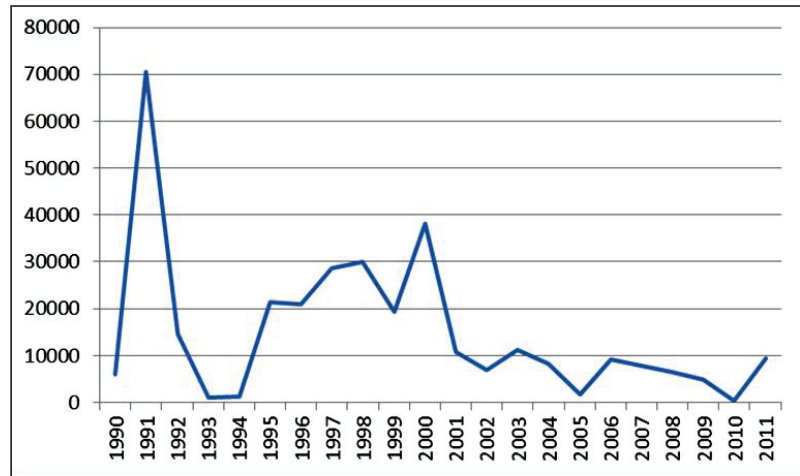

Figure 2: Number of participants (1990-2011)

Source: PEA Left 
One of the key aspects of social justice activism is the scale of its targets. During the first period, a clear prevalence of the national/sub-national framing was evident. The second period was characterized by a growing balance between the two levels. There was a steep decline in the relative number of domestic targets of protest activity in the period (e.g. national political institutions, courts, local authorities); meanwhile this was not compensated for by any increase in foreign and transnational targets (other states, international institutions) (see Figure 3). After 2000, two processes may be identified. First, there was still a close relation in the evolution of the two target scales until 2006. Second, from 2007 an opposite process to that of the previous period took place. There was a growing imbalance between the two target scales, which led to the complete dominance of the national scale of protests by the end of the period; even this was marked by sharp irregularities in their trends. The very end of the period was characterized by protest more than ever aimed at national/sub-national institutions and organizations.

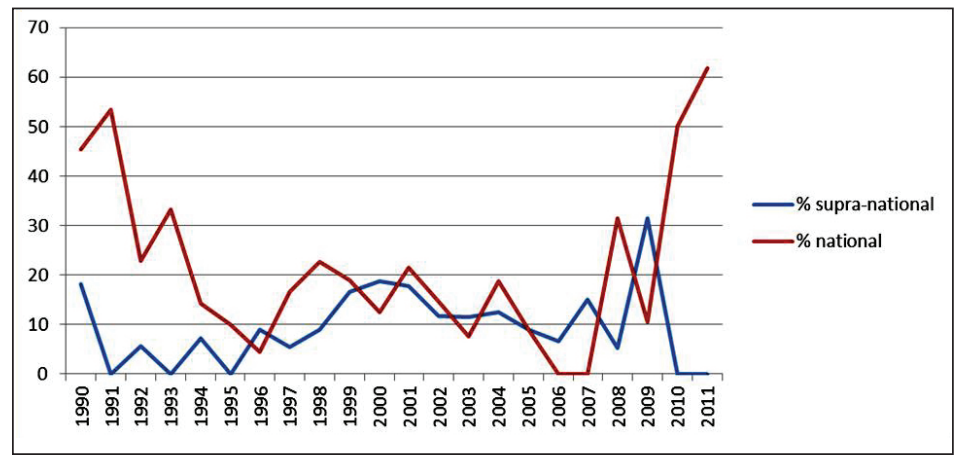

Figure 3: Scale of target (1990-2011)

Source: PEA Left

These shifts in social justice activism were also reflected in the prevailing issues that were raised at the events. The constellation of issues raised during the first period also indicates the openness of the political space for social justice actors and their agenda at the time, which was simply not just the dissemination of radical left ideas but was also closely connected to mobilization against the extreme right and in favor of the democratization of state institutions (see Figure 4).

Almost the same key issues were on the agenda during the second phase of social justice activism, with two important exceptions. First, even though this was an era of increasing internalization of foreign/transnational issues and symbols, it was not dominated by the issue of foreign policy. However, it is apparent that the importance of this issue was on the rise, while the importance of targeting the extreme right declined, together with the promotion of radical Left ideologies and issues. Second, while the economy was never the single most important issue for social justice activism, it nevertheless rose in the 
second half of 1990s and peaked in 2000 with the culmination of global justice activism. On the other hand, the issue of quality democracy and state institutions continued to play an important role (Figure 4).

During the last period, several changes in the trends occurred. Once again, the issue of right wing extremism had become even more important than it was in early 1990s, and most of the other issues remained much less important, with two exceptions. The first was the decline of foreign policy as an issue (with the exception of 2002 and 2007), the second, the quality of democracy and political institutions issue at the end of the period.

More particularly, the changes in the frequency of the foreign policy issue in this phase were strongly negatively correlated with the frequency of the democracy issue (-0.57). On the other hand, there was a very strong positive correlation between the importance of the issues of democracy and economy (0.84). In the previous two periods, the issue of foreign policy was strongly positively correlated with the topic of the economy (0.67), while the relation between the issues of democracy and economy was negative (-0.25).

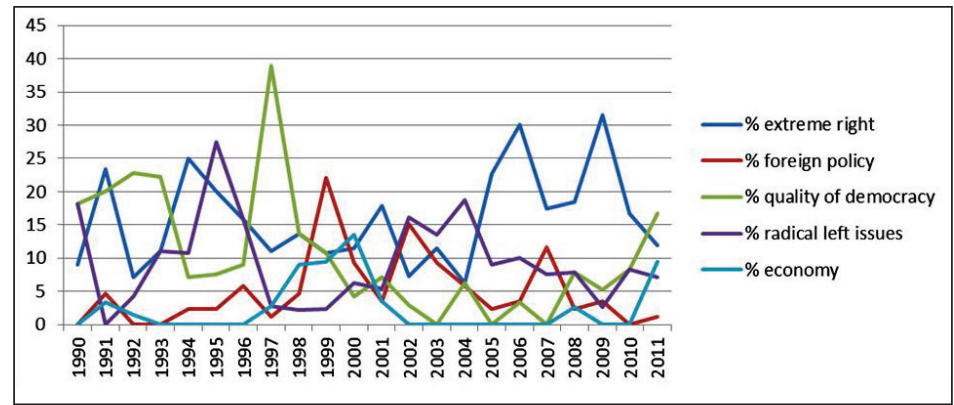

Figure 4: Protest issues (1990-2011)

Source: PEA Left

Apparently, many different but closely-interrelated shifts took place in the trajectory of the Czech social justice movement. Before 2000 we were witnessing the quantitative growth of social justice activism, along with the increased importance of transnational targets, and the increasing importance of the issue of economy - at the expense of the issue of democracy, and focused mostly on the national level. It seems that the issues of democracy and foreign policy were closely interrelated, and dominated at the peak of the movement in 2000.

While it could be expected that there would be some period of decline in global justice protest after the large international event in Prague in 2000, a series of sudden shifts in target scale, importance of issues, and number of events and protest participation after 2007 indicate that other factors and effects rather than just "exhaustion" of the movement might have been at play. The period before the onset of the financial crisis found social justice activism increasingly focused on the national level, articulating problems of economy mostly in connection with the issue of democracy and the quality of national political institutions. Even the arrival of the global financial 
crisis and the subsequent austerity measures effected no change. Two related questions follow from this: first, what mechanisms occurred to prevent social justice activism from raising the scale of contention? Second, how was the character of the movement, or its identity, changed?

\section{Mechanisms of Transformation after 2000}

After 2000, the overall decline of social justice activism may be illustrated by the evolution of protest events explicitly framed as a critique of the political economy of globalization. Street parties as the key form of movement strategy took place in Prague in 2001 and 2002. An annual spinoff of the Prague street parties began in the second largest Czech city, Brno, with approximately the same number of participants over the following years. The framing of these events slowly shifted back from explicit economic alter-globalization towards more environmentally and culturally oriented issues. Street parties, organized mostly by the anarchist sector, were also held as part of the national social forum process that took place in 2004, 2005 and 2007. On the other hand, starting with the NATO summit in Prague in 2002 and continuing with the war in Iraq, the movement gradually started to invest a considerable amount of its energy and capacities into the area of anti-war activism. Generally, while its activities in the field of socio-economic contention were reduced right after 2000, the movement was expanding into the realm of anti-war activism: during the NATO summit, social justice actors organized or coorganized 52\% of anti-war events, during the war in Iraq 50\%, and after 2006, $54 \%$ (PEA Antiwar). Therefore, both of these areas of contention should be examined in order to single out and analyze the mechanism and processes of the movement's decline in the era of financial crisis.

\section{Environmental mechanisms}

One of the key factors that shaped the evolution of the Czech social justice movement was the transformation of its political context. There were two key environments for the movement between 2001 and 2011: the field of socioeconomic contention, and the anti-war field.

The first important shift occurred in late 2002 with the NATO summit in Prague. It was directly related to the intensity of involvement by the social justice movement in the field of anti-war activism, as it provided an opportunity for the movement to deal with anti-war issues from the perspective of international political economy. The political context remained unfavorable: most citizens supported the country's membership in NATO, and the political elite displayed an exceptional consensus in its positive attitudes toward NATO strategies and structures (Šandera, 2002). At the same time, the police took a lesson from the previous international summit and declared a high level of willingness to monitor protesters and to have them under permanent physical control. This, together with soft repression strategies (intimidation of activists through media) and the very limited presence of foreign participants 
and groups, led to an increased level of repression during the events.

The second important shift took place in 2003, when the international threat of war in Iraq arose. First, the preparations for the war in Iraq were launched; then the war itself started in March 2003. From that moment on, the political context for anti-war activism started to open up, as the previous political alignments of major domestic political forces related to the issue changed. The government, a key decision-maker in the Czech political system in the field of international issues and policies, and major political parties underwent serious internal disputes and splits related to the Iraq invasion. Furthermore, the public became opposed to the conflict, and police did not take any repressive measures during anti-war protests, while softening their protest management strategies.

The next important shift in political context took place in August 2006, when anew threat appeared. The potential deployment of a U.S. missile system to the Czech Republic was unexpectedly brought to the forefront of the political agenda. The political context remained open, as the government promoting the deployment was not backed by a majority in Parliament; thus the Parliament became the central political institution dealing with the issue and new alignments appeared. This led to a radical change in the political landscape for extra-parliamentary political mobilization. As in the previous period, there was a pool of influential allies and supporters of anti-war activism (both among the political and cultural elites, and among other nonstate collective actors).

Finally, the era after 2008 was largely characterized by shifts in the socioeconomic context of political contention and a return by the social justice SMOs "back" to the arena of social-economic contention. Right after its installment in mid-2006, the new right-wing government made efforts to promote economic deregulation and pro-market reforms. Liberalization of health care, tax regulation, and the welfare system became effective in January 2008, which opened up opportunities and offered grievances for socio-economic conflict. Political elites were sharply divided on the scope and necessity of austerity measures, and these measures also became largely unpopular among the population.

In late 2008, the first worries about the impact of the global financial crisis on the Czech Republic appeared. While its measurable impact on the Czech economy before 2009 was far from dramatic, the Czech right-wing government had used the notion of crisis to legitimize further liberalization and fiscal restrictions in economic, healthcare, and social policies that would otherwise have been applicable only with significant political costs and difficulties. Even if the government denied that the Czech economy could be directly endangered by the coming financial crisis, it nevertheless threatened citizens with "the Greek example" if there were no further spending cuts and tax growth. The political Right succeeded in framing the crisis as a consequence of "generous and irresponsible left-wing policies" to such an extent that they succeeded in the parliamentary elections in mid-2010. The establishment of a new right-wing government was thus interpreted as 
representing the prevailing agreement of the citizens with austerity policies, and led to the closure of the political context.

However, the government's austerity policies, massive restitution of church property, continuing economic downturn, and corruption scandals among the political elites led to broad disagreement on the part of the public and the political opposition, and the political context for the social justice movement began to open up again.

\section{Relational mechanisms}

After the important milestone of 2000 when social justice SMOs shared some key protest events (even if they did not jointly co-organize them), cooperation among these groups became less frequent again. While the "Stop IMF!" platform was from the very outset considered to be a temporary cooperation intended only for the duration of the summit, INPEG was a very ambitious project. However, it continued to exist for a few more months, and gradually declined after internal disputes broke out (Slačálek, 2000). Non-coalitional events (i.e. events organized by single SMOs) became obviously dominant, and the mechanism of defection became ever more intensive until 2006 (see Figure 5). As indicated above, "pure" social justice events after 2000 were still most frequently organized by single SMOs or by their ideologically defined clusters (namely, by anarchist ones consisting of street parties, and Trotskyites and communists focusing on social forum events).

This trend changed in 2006 when the share of events that were co-organized began to increase, at the expense of events organized by any single SMO. This turnaround was closely tied to coalition-making in the field of anti-war contention. While the context shift in 2003 led to a significant reduction in the role of ideological barriers in forming protest alliances and pushed new actors into the anti-war arena, the imposition of a new threat in 2006 led to the mechanisms of emulation and brokerage, i.e., to the building of broad and firmly-integrated protest platforms on the ground. This led not only to better integration among social justice SMOs but also their engagement with new domestic actors (see Figure 5).

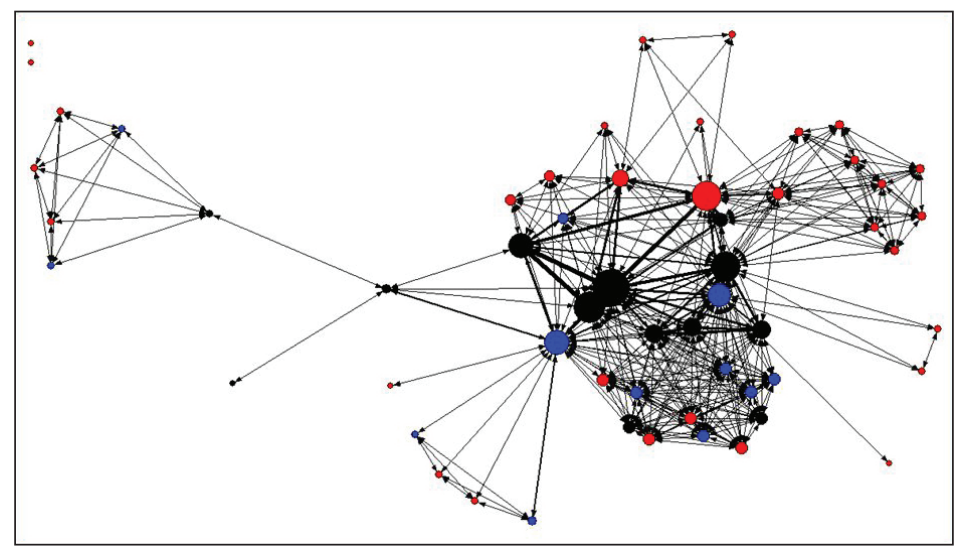




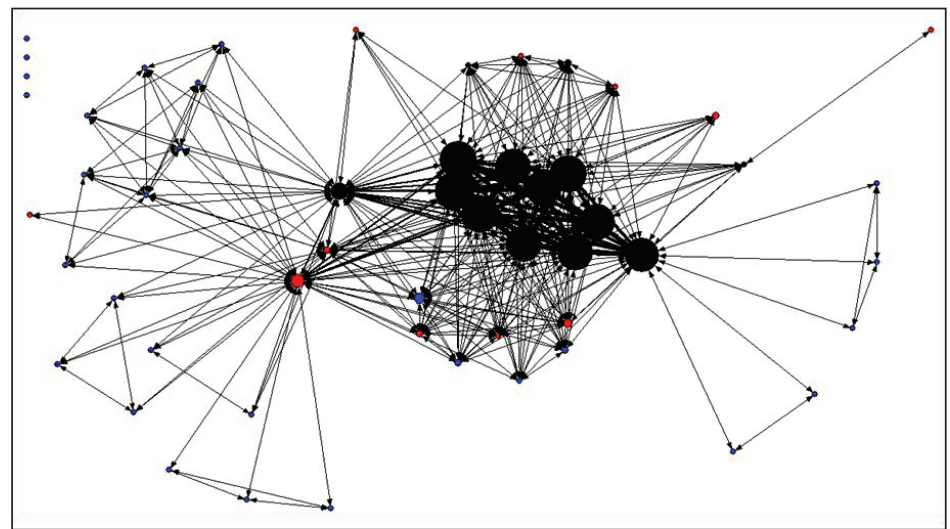

Figure 5: Anti-war protest coalitions (2003-2006 and 2006-2009)

Source: PEA Anti-war

Note: The black areas denote core social justice SMOs, the red ones are those that consider themselves to be part of the movement but are not identified as such on the part of the social justice actors, and the blue ones are other SMOs (environmental, religious etc.). The size of the node denotes its coalitional activity, and the strength of ties denotes the frequency of cooperation between the two nodes.

What is more important, however, is that in 2006 the brokerage mechanism also seemed to operate in the field of social justice and the socio-economic areas. The intensifying of the general brokerage mechanism was interrupted in 2010, when protest events organized by single social justice SMOs generally prevailed, thus fully giving way to the mechanism of defection. Because of the subsequent intensive negotiating and preparations for the new anti-austerity platform, however, the situation changed abruptly next year and the strategy of co-organizing protest events became the only game in town in all issue areas, including social justice. Undoubtedly, the mechanism of brokerage was re-activated.

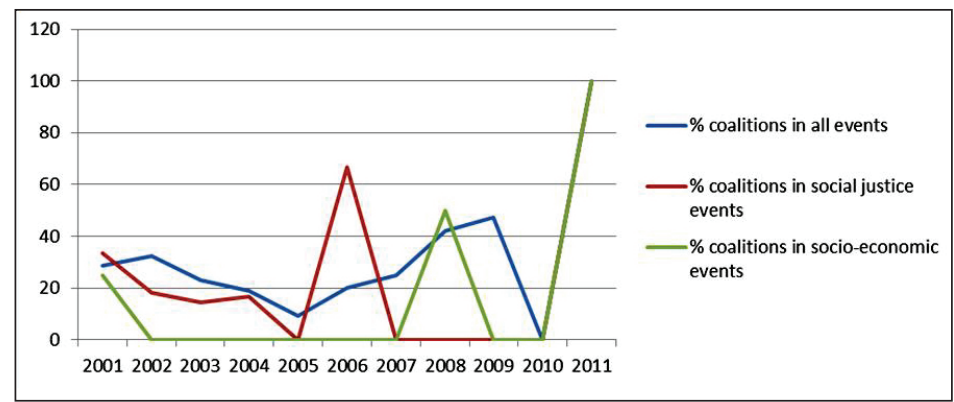

Figure 6: Evolution of protest coalition work (2001-2011)

Source: PEA Left

A general look at the average number of members of protest coalitions reveals two major findings: first, for the most of the period until the U-turn 
in networking strategies in 2010, the most common number of co-organizers of protest events was between two and three. Second, the last year under study is characterized by considerably broader protest coalitions. This further underlines the intensity of the brokerage mechanism (see Figure 6).

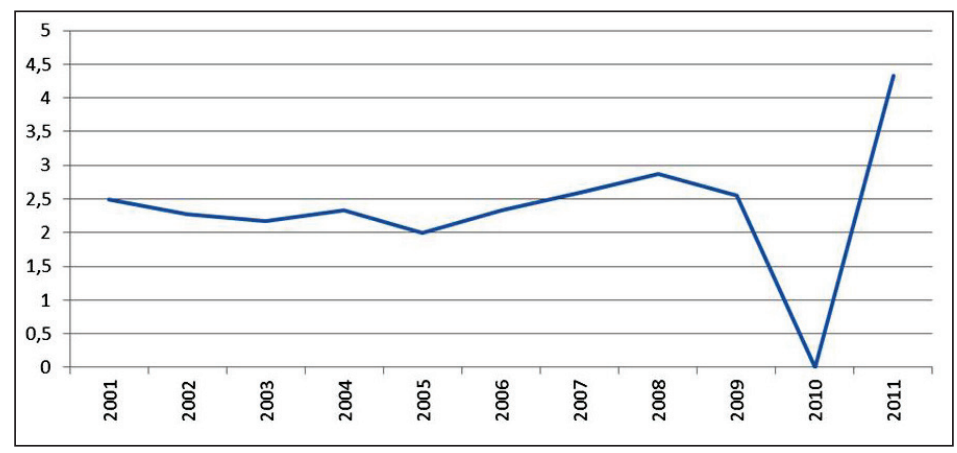

Figure 6: Average number of protest coalition members (2001-2011)

Source: PEA Left

\section{Cognitive mechanisms}

The changing environment and changing relations among social justice actors were closely related to changes in their understanding of the political context and the shaping of their collective identity. The protesters clearly perceived the heightened police repression during the anti-NATO summit in late 2002: "Essentially, all of my peers that are also against NATO simply feared going here and getting into conflict with police"(Kuchyňová, 2002). This fear of attending anti-war or other protest events did not appear again later, and was rather exceptional. The perception of political closure was supplemented by polls of citizens' attitudes towards NATO in which nearly $60 \%$ of respondents displayed their trust in NATO, and 70\% supported Czech membership in the alliance (Šandera, 2002). The prevalent framing of protests during the period was related to the economy (67\%), and claims remained firmly embedded on the supranational level (86\%) (PEA Anti-war).

The start of the war in Iraq was marked by a change in public opinion and by rising serious tensions among political elites: "The attack on Iraq caused doubts even among the Social Democrats that were in the government, which was obviously on the side of NATO during its Prague summit. A skeptical view of USA strategy was shared among a much larger part of society" (Representative of Socialist Solidarity group, interview conducted May 6, 2013).

The released data on citizens' attitudes further showed that two thirds of them opposed a military solution to the situation, and this attitude prevailed for the next three years of the anti-war campaign (Červenka, 2005). Again, the most important type of framing remained the economic one $(88 \%)$, with majority claims remaining on the supranational scale $(81 \%)$, thus showing that the major understanding of these anti-war protests was still mostly related to capitalism and economic interests (PEA Anti-war). 
The next shift in the political context that took place in 2006 was perceived by social justice SMOs as a more dramatic one. Apart from a major shift in their understanding of the nature of the target of the protest, the scale of the perceived threat also changed considerably. Of significance, the most important type of framing used during the protest was related to democracy $(70 \%)$, and the share of claims targeting transnational institutions or organizations rapidly decreased (57\%) (PEA Anti-war). The change in the issues as well as the rising discontent among the population (Červenka, 2009) were perceived by social justice SMOs and were clearly related to their change in strategies: "The issue played its role. The closer it was (not only in terms of geography) to the Czech public, the easier it was to consider its mobilization" (Interview 1).

Essentially, the prevalence of the democracy issue and the shift in attention from the transnational to national level were maintained even during the shift in the socio-economic context of contention related to national economic reforms in 2008. Even if the war in Iraq and the financial crisis were still reflected and debated inside the movement, the issue of domestic economic reforms and their social consequences still prevailed until 2009. In 2009, however, the situation changed. First, the movement utilized the opportunity of Obama's visit to Prague to indicate a change in U.S. foreign policy. Second, the government lost a no-confidence vote and stepped down. Consequently, the movement declared victory in the anti-war campaign. At the same time, the financial crisis hit the country and became part of the national political discourse, and the movement switched to the domestic economic agenda while trying to benefit from its mobilization successes in the anti-war campaign: "Now it is important not to be lulled to sleep by the fall of the government supporting the missile system. It is necessary to demonstrate further that those $70 \%$ of citizens are not just a number but a real power that every future government must take into account" (Molnár, 2009).

Since 2010, the socio-economic agenda has become fully dominant, and the movement has used the opportunity of parliamentary elections (May 2010) to mobilize against the past and future austerity policies of the political Right. While the Social Democrats actually won the elections, conservativepopulist right parties won the majority of seats, and formed a government that supported the focus of the movement on the transformation of domestic politics: "And as I mentioned above, the left-wing parliamentary party is primarily the outcome of a movement, so let's build a movement instead of relying on miracles. There will be a plenty of opportunities for that in the immediate future" (Franke, 2010).

While the perceptions of shifts in the political context were changing quite frequently, it seems that there were only slow shifts in the collective identity of the movement. As described above, individual currents of the movement with different ideological variants on the social justice identity internalized their alter-globalist character around 2000 at the latest. This simultaneous multiple belonging to both the transnational movement and to a particular domestic ideological stream (anarchism, Trotskyism, Marxism, deep 
ecology) enabled their closer coordination, even if their primary ideological particularities never disappeared (Císař \& Slačálek, 2007; Kolářová, 2009, pp. 56-57). This secondary "transnational identity" proved to be quite persistent, and seemed to exist even after the nationalization of the domestic anti-war campaign in 2006. An analysis of a symbolic nomination network after the launch of the domestic phase of anti-war activism (2007) revealed that the self-identification of social justice SMOs and their identification as global justice actors on the part of other members of the movement match very well (Navrátil, 2012, pp. 101-102). At the same time, even after five years of intensive involvement in anti-war activism, only a minor part of the movement embraced what might be called a "peace movement identity" (Navrátil, 2012, p. 97). However, after 2009 it became increasingly evident that the transnational global justice identity had become rather an organizing tool for inner coordination of what might be called the "national social justice movement." This consisted of former global justice actors being engaged in new national platforms, and derived its identity from the achievements of the anti-war movement, and not the global justice movement: "Now the task is to build, and especially in the Czech Republic, the network of individuals and organizations that would find a common will to search the alternative solution of contemporary crisis with respect to autonomy of particular organizations" (Horňáček, 2009).

\section{The Process of Transformation after 2000}

The above-described shifts in the environmental, relational, and cognitive aspects of the Czech social justice movement after 2000 represent constituent parts of two broader and closely intertwined processes: the scale shift and the identity shift. This description should help us understand the paths by which the transformation of the "meta-logic" of the social justice movement's activities occurred. It had previously mobilized against the broad economic and social consequences of neoliberal globalization, while maintaining sparse ties with other actors on the national level. Later, the social justice movement became anchored in the domestic political and social context, and focused on the national instead of transnational institutions and processes.

The intertwining of identity and scale shift processes started with the protests against NATO that launched the movement's spillover into anti-war activism. The counter-summit provided the movement with an opportunity to rely on its international focus and to draw on its global justice identity while emphasizing issues of peace and war. The specific ideological affiliations of the movement still remained activated.

The opening of the political context during the Iraq War was interpreted as an opportunity for the movement to generally continue mobilizing according to its previous socio-economic agenda, but at the same time the mechanism of brokerage became extremely important. The movement began to build on the widely-shared consensus of opposition to the Iraq conflict in Czech 
society and among the political elites after 2003, and substantially increased coordination with other Czech SMOs. Even though peace issues were usually considered part of the global justice agenda, the movement's anti-war focus fostered the brokerage of new domestic coalitions that bridged more ideological gaps than the global justice focus had ever done before. The shift to a different field of political contention enabled ties to be formed with new actors - both with peace SMOs and with former ideological enemies. The favorable context made the movement stay in this area and combine anti-war and global-justice rhetoric. Both the opportunity itself and its framing were still situated firmly on the transnational level.

An unexpected shift in the political context and the resulting perception of an imminent threat in 2006 prevented the movement from making great use of socio-economic framing and anti-capitalist rhetoric, and pushed it into playing the nationalist tune against the "new occupation". This was accompanied by the building of much closer and integrated national platforms with former loose alliance partners and other, newer actors; at the same time, it was backed by unprecedented support from the national public, which the movement attempted to mobilize. The activation of the emulation mechanism once again showed that the former ideological divides within social justice activism could be overcome much more easily in a different field of contention and under imminent threat than in the generally open context of global justice activism. Despite this, the sense of global justice identity persisted even during this phase of the movement's evolution, while the anti-war identity did not take root in the movement. The former alliances belonging to the "international" phase of anti-war activism were used as the foundation for well-organized national networks within which social justice and other SMOs learned how to cooperate effectively. The end of the national anti-war campaign in mid-2009 was interpreted as an unequivocal (and much needed) success, coming at the same moment as the socio-economic conflict in the country was at its height.

The movement switched to this area of contention, but the success of the national anti-war campaign became the main determinant of the movement's subsequent strategies and mode of operation: the ability to effectively organize broad national coalitions with a common cause was utilized for fighting the consequences of the crisis for the citizens and domestic democracy, not for an anti-systemic critique of the transnational political and economic order. A return to the area of socioeconomic contention was followed by the mechanism of emulation of previous anti-war coalitions, but now focused mostly on domestic economic issues and grievances. The emergence of new opportunities in the field of socioeconomic contention and the movement's subsequent shift in that direction after 2008 enabled the movement to return to its original issue, however, this time with almost no long-term supranational focus, global justice framing, or transnational identity. 


\section{Conclusions}

This article focused on the processes of transformation of the Czech social justice movement between its global justice phase and the arrival of the global financial crisis to the country. By tracing the shifts in three aspects of the movement's evolution - environmental, relational, and cognitive - this article argues that the movement's intensive involvement in the field of anti-war activism was itself dramatically transformed in 2006, leading to subsequent changes in its mode of operation and collective identity. The nationalization of anti-war activism had an impact on social justice actors, with several consequences. The global justice movement's identity was transformed into a national social justice one and the movement became anchored in domestic activist networks. Even if this is a case study of Czech social justice activism alone, it may also have broader consequences for other types of activism in general. First, it seems that the changes in transnational opportunity structures might have very serious consequences for the cooperation strategies of social justice (or other) SMOs on the national or even local level. Second, the spillover of the movement into different areas of contention may help the movement to avoid or slow its decline, but may also radically transform the movement's character and have far-reaching consequences for its identity and mode of operation. It seems that the firm embeddedness of the movement in the national inter-organizational networks and social context (in whatever field of contention this takes place) pushes it towards more reflexive and intelligible strategies with regard to the domestic public and its issues, moods and attitudes, but at the same time deprives the movement of an anti-systemic supra-national element of its identity and ethos.

On the other hand, there are still questions that remain unanswered in terms of a broader context of the study of transnational contention. Initially, one may wonder whether the scale shift of social justice activism after 2000 should not be viewed simply as a return to a more "natural" mode of its operation rather than some kind of a shock or recession: before and even during the peak of its transnational activities, Czech social justice actors remained active on a local and national scale as these levels constituted their primary operating environment. Second, aforementioned shifts in a contention scale are always temporary and reversible. This article highlighted the circumstances that have driven the process of scale transformation, and we might hypothesize that diverse outcomes could be observed in a short period of time if these were replaced by different ones. Last, as outlined in the introductory part, this article has focused on the scale shift of particular aspects of collective action, while it has left aside the others (e.g. structures of organization, non-protest cooperation, cross-border communication etc.). This poses apparent limitations on our thorough understanding of the scale of contention dynamics and suggests that further research of the issue is needed. 


\title{
Acknowledgement
}

This work has been supported by the project "Employment of Newly Graduated Doctors of Science for Scientific Excellence" (CZ.1.07/2.3.00/30.0009) co-financed from European Social Fund and the state budget of the Czech Republic, and by the project Collective Action and Protest in East-Central Europe (code GAP404/11/0462) funded by the Czech Science Foundation.

\begin{abstract}
Notes
1 There is a potential bias in this data source. While the data from a nationwide press agency may underrepresent local or politically marginal events, events with controversial and violent content may be overrepresented. Generally, one has to keep in mind that the dataset from the mainstream media may over-represent the events that are attractive for a broader audience (cf. Koopmans \& Rucht, 2002, p. 247).
\end{abstract}

\section{References}

Alimi, E. Y. (2007). The dialectic of opportunities and threats and temporality of contention: Evidence from the Occupied Territories. International Political Science Review 28, 101-123.

Almeida, P. D. (2003). Opportunity organizations and threat-induced contention: Protest waves in authoritarian settings. American Journal of Sociology 109, 345-400.

Ayres, J. M. (2004). Framing collective action against neoliberalism: The case of the "antiglobalization" movement. Journal of World-Systems Research 10, 11-34.

Bastl, M. (2001). Radikální levice v České republice: devadesátá léta dvacátého století. [Radical Left in the Czech Republic]. Brno: IIPS.

Borgatti, S. P., Everett, M. G., \& Freeman, L. C. (2011). UCINET 6 for Windows: Software for Social Network Analysis. Harvard, MA: Analytic Technologies.

Císař, O., \& Slačálek, O. (2007). The alter-globalization movement and democracy in the Czech Republic. Paper presented at the ECPR Joint Session of Workshops. Helsinki, Finland, May $7-12$.

Císař, O. (2008). Politický aktivismus v České republice. Sociální hnuti a občanská společnost $v$ obdobi transformace a evropeizace [Political activism in the Czech Republic. Social movements and civil society in the period of transformation and Europeanization] Brno: CDK.

Císař, O., \& Koubek, M. (2012). Include 'em all? Culture, politics and a local hardcore/punk scene in the Czech Republic. Poetics: Journal of Empirical Research on Culture, the Media and the Arts 40, 1-21.

Červenka, J. (2005). Irák z pohledu veřejného mínění. [Iraq as reflected by the public opinion.]. Public Opinion Research Centre, Institute of Sociology, Academy of Sciences of the Czech Republic. Retrieved from www.cvvm.cas.cz/upl/zpravy/100455s_pm50318.pdf

Červenka, J. (2009). Občané o americké radarové základně v ČR. (Citizens on U.S. radar base in the CR.). Public Opinion Research Centre, Institute of Sociology, Academy of Sciences of the Czech Republic. Retrieved from www.cvvm.cas.cz/upl/zpravy/100894s_pm90415.pdf

Della Porta, D., \& Tarrow, S. (Eds.). (2005). Transnational protest and global activism. Lanham: Rowman \& Littlefield Publishers.

Franke, T. (2010). Sarkastické ohlednutí se za volbami a poněkud méně sarkastické hledění do budoucna. [A sarcastic reflection of elections and somewhat less sarcastic forecast of the future]. Solidarita 44, 3-6.

Goldstone, J. A., \& Tilly, C. (2001). Threat (and opportunity): Popular action and state response in the dynamic of contentious action. In R. Aminzade, D. McAdam, E. Perry, W. Sewell, S. Tarrow, \& C. Tilly (Eds.). Silence and Voice in the Study of Contentious Politics (pp. 


\section{Jiř́ Navrátil}

179-194). Cambridge: Cambridge University Press.

Hadden, J., \& Tarrow, S. (2007). Spillover or spillout? The global justice movement in the United States after 9/11. Mobilization 12, 359-376.

Hamel, P., Lustiger-Thaler, H., Pieterse, J. N., \& Roseneil, S. (Eds.). (2001). Globalization and Social Movements. Houndmills: Palgrave.

Heaney, M. T., \& Rojas, F. (2011). The Partisan Dynamics of Contention: Demobilization of the Antiwar Movement in the United States, 2007-2009. Mobilization 16, 45-64.

Horňáček, J. (2009). Odbory, neoliberalismus a co dál. [Trade unions, neoliberalism and what's next]. Solidarita 33, 4-5.

Juris, J. S. (2008). Networking Futures. The Movements against Corporate Globalization. London: Duke University Press.

Kolářová, M. (2008). Antiglobalismus. (Antiglobalism) Socioweb 4, 3-5.

Kolářová, M. (2009). Protest proti globalizaci. Gender a feministická kritika [Protest against globalization. Gender and feminist critique]. Praha: SLON.

Koopmans, R., \& Rucht, D. (2002). Protest event analysis. In B. Klandermans, S. Staggenborg (Eds.). Methods of Social Movement Research (pp. 231-259). Minneapolis, London: University of Minnesota Press.

Kuchyňová Z. (2002). "Dosud největší demonstrace odpůrců NATO skončila bez incidentů.“ [The biggest demonstration against NATO finished without any incidents]. Radio Praha, $21^{\text {st }}$ November 2002. Available at: http://www.radio.cz/cz/rubrika/udalosti/-dosud-nejvetsidemonstrace-odpurcu-nato-skoncila-bez-incidentu- (last access 21.3. 2014).

McAdam, D., Tarrow, S., \& Tilly, C. (2001). Dynamics of Contention. Cambridge: Cambridge University Press.

McAdam, D., Tarrow, S., \& Tilly, C. (2008). Methods for Measuring Mechanisms of Contention. Qualitative Sociology 31, 307-331.

Molnár, F. (2009). Vzkaz pro Obamu, že radar nechcem. [A message for Obama that we do not want a missile base]. Solidarita 33, 2.

Munck, R. (2007). Globalization and Contestation. Abingdon: Routledge.

Navrátil, J. (2010). Between the Spillover and the Spillout: Tracing the Evolution of the Czech Global Justice Movement. Czech Sociological Review 46, 913-944.

Navrátil, J. (2012). Vývoj českého hnutí za globální spravedlnost v kontextu protiválečného aktivismu v letech 2002-2009. Analýza procesů transformace kolektivních aktérů [Evolution of Czech Global Justice Movement in the context of antiwar activism between 2002-2009. Process tracing of collective actors' transformation]. Ph.D. thesis, http://is.muni.cz/th/52823/ fss_d/

Navrátil, J., \& Císař, O. (2014, forthcoming). Towards a "Non-Global Justice Movement”? Two paths to re-scaling the left contention in the Czech Republic. In D. della Porta \& A. Mattoni (Eds.) Spreading Protest in Social Movements of the Crisis. Colchester: ECPR Press.

Rucht, D. (2009). The Transnationalization of Social Movements: Trend, Causes, Problems. In D. Della Porta, H. Kriesi \& D. Rucht (Eds.). Social Movements in a Globalising World (pp. 206-222). Houndmills: Palgrave Macmillan.

Růžička, V. (2007). Squaty a jejich revolučni tendence [Squats and their revolutionary tendencies]. Praha: Triton.

Slačálek, O. (2000). Stručná historie českého anarchistického hnutí. [A brief history of Czech anarchist movement] A-kontra 8/2000.

Smith. J. (2008). Social Movements for Global Democracy. Baltimore: The Johns Hopkins University Press.

Starr, A., \& Adams, J. (2003). Anti-globalization: The Global Fight for Local Autonomy. New Political Science 25, 19-42.

Šandera, J. (2002). Jaký je vztah našich občanů k NATO? [What are the attitudes of our citizens towards NATO?] Press conference of the Centre for Empirical Research, Prague, 28th January 2003. Retrieved from: http://www.stem.cz/tisk.php?id=399

Tarrow, S. (2005). The new transnational activism. New York: Cambridge University Press.

Tilly, C., \& Tarrow, S. (2007). Contentious Politics. Boulder: Paradigm Publishers.

Welsh, I. (2004). Network Movement in the Czech Republic: Peturbating Prague. Journal of Contemporary European Studies 12, 321-337. 